\title{
Research and Practice of Mathematical Practice Teaching System in Applied Universities
}

\author{
Jie Gao* \\ Zhuhai College \\ Jilin University \\ Zhu hai City, P.R.China \\ jiegao26@163.com
}

\author{
Yasong Liu \\ Computer Science and Technology Department \\ Zhuhai College \\ Jilin University \\ Zhu hai City, P.R.China \\ yasongliu@163.com
}

\begin{abstract}
Against the background of transformation, compared with higher vocational colleges, applied undergraduate colleges should further strengthen the practical teaching of mathematics curriculum in universities in order to cultivate competitive applied undergraduate talents. The purpose of this paper is to introduce how to teach mathematical practice courses in applied undergraduate colleges, and how to choose suitable mathematics models and cases related to various professional learning in applied undergraduate colleges. Finally, the students learning effectiveness has been tested through the practice of mathe matical modeling contest.
\end{abstract}

Keywords-applied undergraduate colleges, practice teaching, and University mathematics

\section{INTRODUCTION}

At present, the number of independent colleges in our country accounts for more than $50 \%$ of the ordinary colleges and universities in our country, which has become an important part of higher education in our country. However, due to the low employment rate of undergraduates in some independent colleges, the Department of Planning proposed to transform most of the local undergraduate colleges, including independent colleges, into applied undergraduate colleges. The Outline of the National Medium and Long-Term Education Reform and Development Plan (2010-2020) clearly put forward the need to optimize the personnel training structure and continuously expand the scale of applied talents training. Guangdong Provincial Department of Education and other departments issued in 2016 to guide some of the general undergraduate colleges and universities to implement the views of the transformation. The main task and goal of applied undergraduate colleges are to cultivate applied talents, and practical teaching is an important part of cultivating applied talents.

The content of college mathematics curriculum has a profound practical application background, and has a wide range of applications in various fields such as natural sciences, social sciences, engineering, military affairs, aviation and industrial and agricultural production. The math course in university plays an important role in cultivating students' maths

This work was supported in part by Colleges and Universities Characteristics of Innovative Projects in the Department of Education of Guangdong Province (Grant No. 2016GXJK200).This work was supported in part by Zhuhai Premier-Discipline Enhancement Scheme and Guangdong Premier Key-Discipline Enhancement Scheme. accomplishment, especially in cultivating students' ability of analyzing and solving problems. At present, most of the independent college maths in many aspects such as syllabus, curriculum system, the allocation of hours, teaching content, teaching philosophy, teaching methods, assessment methods and many other aspects, or directly inherited from the parent institution of the curriculum, or general undergraduate university mathematics teaching content directly to subtract or reduce the curriculum requirements, reduce class arrangements, cut the content of the course, and did not fully take into account the professional curriculum requirements of college mathematics, but did not fully take into account the positioning of personnel training in applied undergraduate colleges.[1] This has caused the dissociation between the university mathematics teaching and the follow-up specialized course teaching as well as the disconnection between the university mathematics knowledge imparting and the practical application ability. Students generally do not feel the role of college mathematics, resulting in low willingness to learn university mathematics. These are not conducive to the realization of the goal of university mathematics teaching, more adverse to the cultivation of applied undergraduate talents. The purpose of this paper is to understand the mathematics models and cases related to various professional learning in applied undergraduate colleges, to design the contents and methods of mathematics practice for these institutions, and to test the students' learning effectiveness through the practice of mathematical modeling contest.[2]

\section{The Connotation of Applied Undergraduate EDUCATION AND THE SIGNIFICANCE OF UNIVERSITY Mathematics Practice Teaching}

Applied talent refers to the application of mature theory and technology to solve practical problems in production and life of technical personnel. Applied Talents Education mainly focuses on cultivating applied talents, cultivating the ability to solve problems as the basis, taking employment as the orientation, realizing the transformation of scientific principles into decision-making design, and finally forming products with certain social benefits through skill operation. Practice teaching is a teaching activity based on the essence and law of cognition, the characteristics and functions of practice, and the purpose and requirements of teaching itself. It is an effective way to consolidate theoretical knowledge and deepen the 
understanding of theory, and it is also an effective way to cultivate students with comprehensive analytical skills, operational ability and ability to collaborate innovative ability of high-quality talent which is an important part of the theory with practice, training students to master the scientific method and improve the ability of an important platform[3].

The traditional method of learning mathematics is taught by the teacher, students practice. This model overemphasizes the dominant position of teachers in the learning process, which is not conducive to giving play to the subjective initiative of students. In the process of teaching, it only focuses on cultivating the students' ability of calculation and logical reasoning while neglecting students' independent thinking and autonomy practice, the ability of independent innovation. Under the guidance of the traditional teaching mode, the students' understanding of mathematics only stays on the memorizing formulas, theorems, computational questions and complicated theoretical proof questions, which are far from the requirements of today's information society for talents. Therefore, to further improve students' ability to apply, to innovate and to strengthen practical teaching is the core content of the current university reform in mathematics, and it should also focus on the cultivation of applied undergraduate colleges. In today's society, students can take full advantage of the rapid development of computer software and hardware to apply mathematical theory knowledge to practice.

\section{ApPlied Undergraduate College Mathematics Teaching System Design PRinciPles}

In applied undergraduate colleges, the implementation of university mathematics practice teaching should meet the requirements of the training objectives of applied talents, embody the essence of applied talents cultivation, focus on the cultivation of abilities and comprehensive qualities, and basically follow the following principles[4].

\section{A. The principle of adaptability}

The objective of training the mathematics practice teaching system in applied undergraduate colleges should be adapted to the needs of the development of social industry and the personnel training mode, and should be adapted to the changing market requirements. Therefore, the practical teaching of applied undergraduate education should establish quality education as the core and technology application ability as the main line, and constantly updated talent education and training mode. As a basic subject of public science, university mathematics should be closely integrated with various professional training programs, embodying the supporting role of mathematical theory in professional skills and adapting to the needs of the society for the capabilities that professionals possess.

\section{B. Comprehensive principle}

The practice teaching system is an organic system composed of teaching elements, teachers' team, and evaluation system and laboratory software and hardware construction. It is necessary to take all factors into consideration such as theoretical teaching and practical teaching, teacher training and laboratory construction so as to achieve overall effect, so as to ensure the efficient operation of the practice teaching system and create a good environment for the cultivation of applied talents.

\section{The Practical principles}

The construction of practical teaching system should fully reflect the specific requirements of professional positions, so it is necessary to form a practical teaching system with strong application background. University mathematics practice teaching system should highlight the ability of technology and innovation as the main line, through practical problems in various fields to cultivate students' ability to solve problems.

\section{Construction of Practical Teaching System in COLLEGE MATHEMATICS CURRICULUM}

The course of mathematics practice in college mainly includes two aspects: one is the abstract and difficult to understand the mathematical concepts and theoretical results through mathematical software for visual reproduction, in order to deepen understanding; the second is as a mathematical modeling course based on mathematical knowledge and knowledge simple application, which is to guide students from the actual problem, after careful analysis and research, the establishment of a simple mathematical model, and by means of advanced computer technology, hands-on programming, onmachine operation to find one or more solutions to the problem.

Most of the contents of the course of mathematics practice in universities are selected from basic math courses of higher mathematics, linear algebra, probability and statistics. After the actual problems are simplified, simplified and linearized, they finally come down to a simpler form. Its content in the depth and breadth of the mathematics are usually between the basic courses and mathematical modeling. Mathematics teaching is the transitional content. In the teaching system, construction can be carried out from the following three levels[5].

\section{A. Basic experimental content}

In addition to the traditional classroom teaching, exercises teaching, routine homework and other aspects of the same time, university mathematics curriculum should be added computer math experiments, that is, through the use of mathematical software on the computer for scientific computing. For example, in advanced mathematics courses, you can use Matlab software to find the limit, find derivatives, integral and other operations, study the law of function changes, draw curves, surface graphics, and verification theorem, and explore new laws and so on. In the linear algebra course, you can use Matlab software such as matrix calculation, determinant calculation, as well as matrix eigenvalues, eigenvectors, orthogonalization and other calculations. In the course of probability and statistics, we can use R language or Matlab to calculate the probability distribution of random variables, generate sample random numbers according to special distribution, and draw the statistical charts and so on. 


\section{B. Comprehensive experimental content}

Select the content that has strong application background in practice, such as optimization problems, portfolio problems, etc., to guide students to use Matlab software to transform application problems into linear programming problems or integer programming problems, as well as nonlinear function to solve the extreme value problem, so that students have the ability to design algorithms, program, error estimates which will deal with algorithm convergence problem.

\section{Simple modeling experiment content}

We select some simplified practical problems and transform them into mathematical models and solve them, for example, establishing mathematical models by using differential equations and using Matlab software to solve and numerical solutions, or by data fitting, interpolation and other methods to make predictions. We guide students to use $\mathrm{R}$ language and other tools for data preprocessing, data cleaning and other work, and data analysis, mining and other work.

\section{College Mathematics Teaching Practice And ACHIEVEMENTS}

The emergence of mathematical practice teaching in universities is the reform of mathematical education mode in traditional universities, which has changed the concept of mathematics education in our university, changed the teaching method from concept to problem-based teaching, instilled students 'theoretical knowledge into students' self-exploration Law, solve the problem. During instruction, teachers should highlight the following points[6].

\section{A. Intuitive}

Teachers should pay attention to case teaching in the process of mathematical practice teaching, pay attention to the dynamic of mathematics teaching reform both at home and abroad, attach importance to computer aided teaching, national college students mathematical modeling contest and so on. Through various visual teaching, students can understand with the most simple and intuitive method, and mask the theoretical knowledge and practical ability.

\section{B. Subjectivity}

Students are the main body of learning and practical operation. To make students learn from active acceptance to active participation and solve problems by learning knowledge, this can stimulate students desire to learn new knowledge, spontaneously find or retrieve relevant books and materials, and then experiment to get the result, to love learning, active learning purposes.

\section{Practicality}

Training math models through mathematical practice courses and using computer analysis to deal with practical problems requires students to have insight, understanding and abstraction on practical issues, to have mathematical modeling skills, and to be able to design mathematical models that have been established algorithm, programming, on-machine computing, and analysis of the results can be calculated and processed, so as to effectively solve practical problems.

\section{CONCLUSION}

In short, we actively explore the application of undergraduate colleges and universities in the orientation of mathematical practice teaching mode, to carry out mathematical modeling and mathematical experiment teaching content and methods of research and practice, organize our school students in the United States mathematical modeling contest, the National Mathematics Modeling competition, national data and other important events to make excellent achievements in the past three years. The mathematics teaching reform in applied undergraduate colleges should conform to the development trend of the times, conform to the orientation of personnel training, focus on cultivating applied talents, improve the comprehensive ability of students, determine the students' knowledge structure and ability structure according to market needs, and optimize the whole Teaching content, so that math courses better applied to professional courses. How to carry out the reform of college mathematics teaching in application-oriented colleges and universities is a very significant topic and has won the attention and emphasis of the majority of mathematics educators.

\section{ACKNOWLEDGMENT}

This work was supported in part by Colleges and Universities Characteristics of Innovative Projects in the Department of Education of Guangdong Province (Grant No. 2016GXJK200).This work was supported in part by Zhuhai Premier-Discipline Enhancement Scheme and Guangdong Premier Key-Discipline Enhancement Scheme.

\section{REFERENCES}

[1] Chen Xifu, Zhou Hai. Application-based undergraduate practical teaching management system construction [J] science and technology information, 2007.12(In Chinese)

[2] Zhu Qing Huan. Construction and Exploration of Applied Practical Teaching System in Newly-built Undergraduate Colleges [J] Guangdong Peizheng College, 2009.4(In Chinese)

[3] Zhang Chuang, China applied undergraduate education practice teaching research [D] Nanchang University. 2007(In Chinese)

[4] Qin Yueyue, college applied undergraduate education mode research and practice [D] Chongqing University, 2009(In Chinese)

[5] BIA N Yu, New Applied Practical Undergraduate Teaching Research [D] Nanjing Normal University, 2011(In Chinese)

[6] Yang Wenjing. Higher mathematics teaching reform and exploration [J] higher science education .2008 (01).(In Chinese) 